\title{
EVALUASI PENYAJIAN DAN PENGUNGKAPAN ASET TETAP BERDASARKAN PSAK NO. 16 PADA PT. AKAM
}

\author{
Hosianita Fiandani Hukom ${ }^{1}$, Jenny Morasa ${ }^{2}$ Sonny Pangerapan ${ }^{3}$ \\ 1,2,3 Jurusan Akuntansi, Fakultas Ekonomi dan Bisnis, Universitas Sam Ratulangi, Jl. Kampus Bahu, Manado, \\ 95115, Indonesia
}

Email : hosianitaf@gmail.com

\begin{abstract}
A prime company entity can be seen through the company's financial statement that is based on Financial Accounting Standards as a guidance in producing the financial statement. Fixed assets is a supporting element which has a quite large value and an important position in a company, therefore the information about the asset should comply with the prevailing standards. The aim of this research is to find out whether the presentment and disclosure of regular assets at PT. AKAM are in conformity with the Statement of Financial Accounting Standards (SFAS) No. 16 concerning property and equipment. The writer uses descriptive method, and the data collection was through interview, observation, and documentation. PT. AKAM is a company entity that engaged in construction service. According to the research result, it can be concluded that the presentment and disclosure of company fixed assets have led to Statement of Financial Accounting Standards (SFAS) No.16.

Keywords : Presentment, Disclosure, Fixed Asset, SFAS 16.
\end{abstract}

\section{PENDAHULUAN}

Pelaksanaan pembangunan di berbagai sektor khususnya di bidang usaha semakin berkembang pesat, dengan didukung oleh kemajuan ilmu pengetahuan, teknologi dan globalisasi akan berdampak pada timbulnya persaingan yang ketat di antara perusahaan, khususnya yang bergerak dalam bidang usaha sejenis. Hal ini menuntut perusahaan untuk lebih efisien dan efektif dalam memanfaatkan sumber daya yang dimiliki perusahaan, agar perusahaan dapat tetap bertahan dalam persaingan global saat ini. Dalam mencapai sebuah tujuan, perusahaan selalu dihadapkan dengan berbagai permasalahan dari bagian internal maupun bagian eksternal perusahaan. Peranan akuntansi sangat dibutuhkan dalam membantu memperlancar aktivitas perusahaan. Dari proses akuntansi tersebut dapat dihasilkan laporan keuangan yang dapat dipakai dalam melihat informasi keuangan atau aktivitas dari perusahaan tersebut.

Suatu entitas perusahaan yang unggul bisa terlihat dari laporan keuangan perusahaan yang didasarkan pada Standar Akuntansi Keuangan yang digunakan sebagai pedoman dan acuan dalam pembuatan laporan keuangan. Laporan keuangan tersebut akan memberikan informasi yang efisien kepada pemakai laporan keuangan baik terhadap pihak internal maupun pihak eksternal perusahaan. Dalam mendukung kegiatan operasional perusahaan, setiap perusahaan pasti memiliki faktor-faktor pendukung dalam proses produksi untuk menghasilkan output berupa barang maupun jasa. Salah satu sumber pendukung dalam kegiatan operasional perusahaan yaitu aset perusahaan. Aset tetap dari suatu perusahaan merupakan bagian yang signifikan dari keseluruhan aset yang dimiliki perusahaan tersebut. Untuk memaksimalkan peranan tersebut, aset tetap harus diberikan perhatian yang memadai serta dibutuhkan kebijakan yang tepat dalam pengelolaan aset tetap. Para pengambil keputusan akan sangat memerlukan alat informasi aset tetap berupa daftar aset tetap dan akumulasi penyusutannya yang disajikan dalam laporan keuangan. Oleh karena itu penyajian dan pengungkapan aset tetap harus memadai sesuai dengan standar akuntansi keuangan. 
PT. AKAM merupakan entitas perusahaan yang bergerak dalam bidang konstruksi, yang tentunya perusahaan ini memiliki berbagai jenis aset tetap. Aset tetap yang sangat penting dalam menunjang kegiatan operasional adalah bangunan, tanah, alat-alat konstruksi, kendaraan dan inventaris kantor. Maka aset tetap perusahaan harus disajikan dan diungkapkan secara efisien karena sangat berkaitan dengan keandalan suatu laporan keuangan agar tidak terjadi miss interpretation yang mana sangat mempengaruhi kebutuhan informasi para stakeholders.

\section{TINJAUAN PUSTAKA}

\subsection{Akuntansi}

Menurut Wild, Shaw dan Chiappetta (2014:3) menyatakan akuntansi adalah sistem informasi dan pengukuran yang mengidentifikasi, mencatat dan mengkomunikasikan informasi yang relevan, dapat diandalkan, dan dapat dibandingkan tentang kegiatan bisnis organisasi. Menurut Kartikahadi (2015:3), Akuntansi adalah suatu sistem informasi keuangan yang bertujuan untuk menghasilkan dan melaporakan informasi yang relevan bagi berbagai pihak yang berkepentingan. Dari beberapa pengertian tersebut dapat disimpulkan bahwa akuntansi adalah proses pencatatan dan pengklasifikasian dari suatu peristiwa ekonomi menjadi suatu informasi keuangan yang merupakan komponen penting dari perusahaan sehingga memungkinkan adanya pelaksanaan dan penilaian jalannya perusahaan secara efisien.

\subsection{Akuntansi Keuangan}

Akuntansi keuangan adalah bagian dari akuntansi yang berkaitan dengan penyiapan laporan keuangan untuk pihak luar, seperti pemegang saham, kreditor, pemasok, serta pemerintah. Prinsip utama yang dipakai akuntansi keuangan dalam persamaan akuntansi (aset $=$ kewajiban + ekuitas). Hal penting dari akuntansi keuangan adalah adanya standar akuntansi keuangan (SAK) yang merupakan aturan-aturan yang harus digunakan di dalam pengukuran dan penyajian laporan keuangan untuk kepentingan eksternal.

\subsection{Laporan Keuangan}

Menurut Kasmir (2016:7), laporan keuangan adalah laporan yang menunjukkan kondisi keuangan perusahaan pada saat ini atau dalam suatu periode tertentu.

Menurut Pernyataan Standar Akuntansi Keuangan Nomor 1 paragraf 10 (revisi 2016) laporan keuangan lengkap terdiri dari :

a. laporan posisi keuangan pada akhir periode;

b. laporan laba rugi dan penghasilan komprehensif lain selama periode;

c. laporan perubahan ekuitas selama periode;

d. laporan arus kas selama periode;

e. catatan atas laporan keuangan, berisi kebijakan akuntansi yang signifikan dan informasi penjelasan lain;

ea. informasi komparatif mengenai periode terdekat sebelumnya sebagaimana ditentukan dala paragraf 38 dan 38A; dan

f. laporan posisi keuangan pada awal periode terdekat

\subsection{Aset Tetap}

Pradana (2015) mengungkapkan bahwa aset tetap adalah aset yang digunakan perusahaan sebagai entitas bisnis untuk menciptakan pendapatan yang berasal dari aktivitas investasi perusahaan. Aset tetap memiliki wujud fisik dan memberikan manfaat ekonomi kepada entitas bisnis selama lebih dari satu periode akuntansi pada masa-masa yang datang. Lubis (2017:29) mengungkapkan bahwa aset tetap adalah aset yang dimiliki dan digunakan perusahaan yang jangka waktunya lebih dari satu tahun dan mempunyai masa manfaat yang mempunyai nilai susut (nilai kegunaan semakin lama semakin berkurang). 
Dari beberapa pengertian di atas dapat disimpulkan bahwa kriteria agar suatu aset perusahaan dapat disebut sebagai aset tetap apabila suatu aset mempunyai wujud fisik, mempunyai umur manfaat lebih dari satu tahun, digunakan dalam kegiatan operasional perusahaan, tidak untuk dijual, dan memiliki nilai manfaat/perolehan relatif besar.

\section{Klasifikasi Aset Tetap}

Dalam PSAK No. 16 (paragraf 37) klasifikasi aset tetap menurut kelasnya dimana suatu kelas aset tetap adalah pengelompokan aset-aset yang memiliki sifat dan kegunaan yang serupa dalam operasi entitas. Berikut adalah contoh dari kelas tersendiri:

1. Tanah

2. Tanah dan bangunan

3. Mesin

4. Kapal

5. Pesawat udara

6. Kendaraan bermotor

7. Perabotan

8. Peralatan kantor

\section{Harga Perolehan Aset Tetap}

Harga perolehan aset tetap yaitu keseluruhan biaya yang dikeluarkan untuk mendapatkan aset tersebut hingga aset tetap siap untuk beroperasi. Harga perolehan aset tetap terdiri dari harga dari aset tersebut, asuransi aset untuk pengiriman aset, ongkos transport untuk pengantaran aset, biaya pemasangan aset tetap dan biaya-biaya lain hingga aset tersebut dapat beroperasi.

\section{Cara Perolehan Aset Tetap}

Menurut Hery (2014:125), Selain dibeli secara tunai, aset juga dapat diperoleh melalui :

1. Pembelian Gabungan

2. Pembelian Kredit

3. Sewa Guna Usaha Modal

4. Pertukaran Aset Tetap

5. Penerbitan Sekuritas

6. Konstruksi (bangun) sendiri

7. Donasi (sumbangan)

\subsection{Akuntansi Aset Tetap}

Akuntansi Aset tetap terbagi sebagai berikut.

\section{Pengakuan Aset Tetap}

PSAK No.16 paragraf 07 menyatakan bahwa aset tetap harus diakui jika dan hanya jika (paragaraf 7).

a. Besar kemungkinan manfaat ekonomis yang berhubungan dengan aset tersebut akan mengalir ke perusahaan; dan

b. Biaya perolehan aset dapat diukur secara andal.

Kriteria pertama dipenuhi apabila tingkat kepastian aliran manfaat ekonomis pada saat pengakuan awal. Pada umumnya kriteria ini dipenuhi apabila risiko dan imbalan kepemilikan aset tersebut telah diterima oleh perusahaan.

\section{Pengukuran Aset Tetap}

a. Pengukuran Awal

Martani (2016:272) menyatakan, suatu aset tetap yang memenuhi kualifiasi untuk diakui sebagai aset pada awalnya harus diukur sebesar biaya perolehan. Biaya perolehan aset tetap meliputi berikut ini.

1. Harga perolehannya, termasuk bea impor dan pajak pembelian yang tidak boleh dikreditkan setelah dikurangi diskon pembelian dan potongan-potongan lain. 
2. Biaya-biaya yang dapat diatribusikan secara langsung untuk membawa aset ke lokasi dan kondisi yang diinginkan agar aset siap digunakan sesuai dengan keinginan dan maksud manajemen,

3. Estimasi awal biaya pembongkaran dan pemindahan aset tetap dan restorasi lokasi aset.

b. Pengukuran Setelahnya

Setelah pengakuan awal atas aset tetap, entitas harus memilih model biaya (cost model) atau model revaluasi (revaluation model) sebagai kebijakan akuntansinya. Model yang dipilih oleh entitas harus diterapkan oleh seluruh aset dalam golongan yang sama. Kebijakan akuntansi tersebut tidak perlu diterapkan untuk semua aset tetap milik perusahaan.

\section{Penyusutan Aset Tetap}

Ikatan Akuntansi Indonesia mengungkapkan bahwa metode-metode penyusutan dapat dilakukan dengan berbagai metode yang dapat dikelompokkan menurut kriteria berikut:

a. Metode Garis Lurus (Straight Line Method)

Formula yang digunakan untuk menghitung penyusutan adalah :

Penyusutan $=\frac{\mathrm{HP}-\mathrm{NR}}{\mathrm{N}}$

Keterangan :

$$
\begin{aligned}
& \mathrm{HP}=\text { Harga Perolehan } \\
& \mathrm{NR}=\text { Nilai Residu } \\
& \mathrm{N}=\text { Taksiran Umur Kegunaan }
\end{aligned}
$$

b. Metode Saldo Menurun (Diminishing Balance Method)

Formula yang digunakan untuk menghitung penyusutan adalah :

Penyusutan $=[(100 \%:$ Umur Ekonomis $) \times 2] \times$ Nilai perolehan/Nilai buku

c. Metode Jumlah Unit (Sum Of The Unit Method)

Formula yang digunakan untuk menghitung penyusutan adalah :

$$
\text { Depresiasi }=\frac{\mathrm{HP}-\mathrm{NS}}{\mathrm{N}}
$$

Keterangan :

$$
\begin{aligned}
\mathrm{HP} & =\text { Harga Perolehan } \\
\mathrm{NS} & =\text { Nilai Sisa } \\
\mathrm{N} & =\text { Taksiran jumlah jam jasa }
\end{aligned}
$$

\section{Penghentian Pengakuan dan Pelepasan Aset Tetap} pengakuannya:

PSAK 16 (paragraf 67) revisi 2016 menyatakan, jumlah tercatat aset tetap dihentikan

a. Pada saat pelepasan; atau

b. Ketika tidak terdapat lagi manfaat ekonomis masa depan yang diharapkan dari penggunaan dan pelepasannya.

Pelepasan aset tetap dapat dilakukan dengan berbagai cara yaitu :

1. Penjualan aset tetap;

2. Penghapusan aset tetap dari semua rekening yang bersangkutan;

3. Disewakan dalam sewa pembiayaan atau disumbangkan;

4. Pertukaran aset tetap sejenis/ tidak sejenis.

\section{Penyajian Aset Tetap}

Menurut Martani (2016:290), aset tetap disajikan dilaporan posisi keuangan (laporan perubahan ekuitas) dibagian aset tidak lancar. Penyajian aset tetap dalam laporan keuangan secara wajar dan benar akan sangat membantu manajemen perusahaan dalam menyampaikan informasi keuangan yang dapat dipercaya kepada pihak-pihak yang berkepentingan dan dapat digunakan untuk menentukan kegiatan perusahaan serta dalam pengambilan keputusan. 


\section{Pengungkapan Aset Tetap}

Menurut Suwardjono (2014:578), pengungkapan secara konseptual merupakan bagian integral dari pelaporan keuangan. Secara teknis, pengungkapan merupakan langkah akhir dalam proses akuntansi yaitu penyajian informasi dalam bentuk seperangkat penuh statemen keuangan.

\subsection{Penyajian Aset Tetap}

Menurut PSAK No. 1 dalam laporan keuangan, penyajian aset tetap akan terlihat dalam neraca. Neraca merupakan suatu daftar yang menggambarkan komposisi harta, kewajiban dan modal pada suatu periode tertentu. Ernawati (2014) menyatakan bahwa di neraca, aset tetap di dicatat sebesar nilai bukunya, yaitu harga perolehan aset tetap tersebut dikurangi dengan akumulasi depresiasi aset tetap.

\section{Unsur-unsur Penyajian Aset Tetap}

Berikut ini adalah unsur-unsur penyajian aset tetap.

1. Laporan Neraca

Jenis-jenis aset tetap yang disajikan dalam neraca diantaranya:
a. Tanah
b. Bangunan
c. Kendaraan
d. Peralatan
e. Inventaris Kantor

2. Laporan Laba Rugi

a. Di dalam laporan laba rugi, dilaporkan biaya pemeliharaan dan reparasi sehari-hari.

b. Beban penyusutan yang merupakan pengakuan atas penggunaan manfaat potensial dari suatu aset.

c. Keuntungan atau kerugian yang timbul dari penghentian atau pelepasan aset tetap.

3. Laporan Arus Kas

a. Pembayaran sejumlah kas untuk memperoleh aktiva tetap

b. Penerimaan kas dari penjualan aktiva tetap

\subsection{Pengungkapan Aset Tetap}

Pengungkapan aset tetap dalam laporan keuangan merupakan penjelasan dari pos-pos aset tetap dalam laporan keuangan. PSAK 16 revsi 2016 (paragraf 73) menyatakan, laporan keuangan harus mengungkapkan untuk setiap kelas aset tetap sebagai berikut:

1. dasar pengukuran yang digunakan dalam menentukan jumlah tercatat bruto;

2. metode penyusutan yang digunakan;

3. umur manfaat atau tarif penyusutan yang digunakan;

4. jumlah tercatat bruto dan akumulasi penyusutan (digabungkan dengan akumulasi rugi penurunan nilai) pada awal dan akhir periode; dan

5. Rekonsiliasi jumlah tercatat pada awal dan akhir periode yang menunjukkan:

a. penambahan;

b. aset yang diklasifikasikan sebagai dimiliki untuk dijual atau termasuk dalam kelompok lepasan yang diklasifikasikan sebagai dimiliki untuk dijual sesuai dengan PSAK 58: Aset tidak lancar yang dimiliki untuk dijual dan operasi yang dihentikan dan pelepasan lain;

c. perolehan melalui kombinasi bisnis;

d. peningkatan atau penurunan akibat dari revaluasi sesuai dengan paragraf 31,39 dan 40 serta dari rugi penurunan nilai yang diakui atau dibalik dalam penghasilan komprehensif lain sesuai dengan PSAK 48; Penurunan Nilai Aset;

e. rugi penurunan nilai yang diakui dalam laba rugi sesuai dengan PSAK 48;

f. pembalikan rugi penurunan nilai dalam laba rugi sesuai dengan PSAK 48;

g.penyusutan; 
h. selisih kurs neto yang timbul dalam penjabaran laporan keuangan dari mata uang fungsional menjadi mata uang pelaporan yang berbeda, termasuk penjabaran dari kegiatan usaha luar negeri menjadi mata uang pelaporan dari entitas pelapor; dan

i. perubahan lain

PSAK No.16 revisi 2016 (paragraf 74) menyatakan, laporan keuangan juga harus mengungkapkan:

1. keberadaan dan jumlah pembatasan atas hak milik dan aset tetap yang dijaminkan untuk liabilitas;

2. jumlah pengeluaran yang diakui dalam jumlah tercatat aset tetap yang sedang dalam konstruksi;

3. jumlah komitmen kontraktual untuk memperoleh aset tetap; dan

4. jumlah kompensasi dari pihak ketiga untuk aset tetap yang mengalami penurunan nilai, hilang, atau dihentikan yang termasuk dalam laba rugi, jika tidak diungkapkan secara terpisah dalam laporan laba rugi dan penghasilan komprehensif lain.

Pengungkapan metode yang digunakan dan estimasi umur manfaat atau tarif penyusutan menyediakan informasi bagi pengguna laporan keuangan dalam mengkaji kebijakan yang dipilih manajemen dan memungkinkan perbandingan dengan entitas lain, Untuk alasan yang serupa, juga perlu diungkapkan:

1. penyusutan, apakah diakui dalam laba rugi atau diakui sebagai bagian dari biaya perolehan aset lain, selama satu periode; dan

2. akumulasi penyusutan pada akhir periode.

PSAK 16 revisi 2016 (paragraf 77) menyatakan, jika aset tetap disajikan pada jumlah revaluasian, hal berikut diungkapkan sebagai tambahan pengungkapan yang disyaratkan oleh PSAK 68: Pengukuran nilai wajar:

1. tanggal efektif revaluasi

2. apakah melibatkan penilai independen;

3. untuk setiap kelas aset teap yang direvaluasi, jumlah tercatat aset seandainya aset tersebut dicatat dengan model biaya; dan

4. surplus revaluasi, yang mengindikasikan perubahan selama periode dan setiap pembatasan distribusi kepada pemegang saham.

\subsection{Penelitian Terdahulu}

Mustamin (2013) dalam penelitian Analisis Pengakuan, Pengukuran dan Pelaporan pada PT Hasjrat Abadi Cabang Manado berdasarkan PSAK nomor 16. Hasil penelitian menunjukkan Penerapan konsep akuntansi mengenai pengakuan dan pengukuran aktiva tetap yanag diterapkan oleh PT. Hasjrat Abadi telah sesuai dengan Standar Akuntansi Keuangan.

Pontoh (2016) dalam penelitian Evaluasi Penerapan Perlakuan Akuntansi Terhadap Aktiva Tetap Berdasarkan PSAK NO.16 Tahun 2011 Pada PT. Nichindo Manado Suisan. Perlakuan akuntansi aktiva tetap yang diterapkan peusahaan sudah mengarah pada PSAK NO.16. perusahaan menyusutkan aktiva tetapnya menggunakan metode saldo menurun dimana hal ini belum sesuai dengan standar akuntansi yang berlaku, perusahaan menghentikan aktiva tetap yang sudah tidak digunakan dengan cara menghapus aktiva tetap yang sudah tidak digunakan seperti aktiva tetap dari daftar kepemilikan dan melepasnya dengan cara dihibahkan. Perushaan telah menyajikan laporan keuangan yang sesuai dengan standar akuntansi keuangan.

\section{METODE PENELITIAN}

\subsection{Jenis Penelitian}

4.

Jenis penelitian ini yang digunakan dalam penelitian ini adalah penelitian deskriptif dengan pendekatan kualitatif.

\subsection{Tempat dan Waktu Penelitian}


Penelitian di laksanakan pada PT. AKAM yang berlokasi di Jln. A.M. Sangaji Km.12, Kota Sorong, Papua Barat. Waktu penelitian yang dibutuhkan kurang lebih dua bulan. Periode waktu penelitian di mulai pada bulan Februari - April 2018.

\subsection{Metode Pengumpulan Data}

\section{Jenis Data}

Jenis-jenis data yang digunakan dalam penelitian ini adalah sebagai berikut.

1. Data kuantitatif dalam penelitian ini adalah laporan keuangan perusahaan tahun 2015 dan 2016.

2. Data kualitatif dalam penelitian ini adalah catatan yang berhubungan dengan aset tetap dan ikhtisar kebijakan akuntansi perusahaan yang berhubungan dengan aset tetap.

\section{Sumber Data}

1. Data primer pada penelitian ini berupa data laporan keuangan PT. AKAM tahun 2015 dan 2016 dan data berupa hasil wawancara dengan pihak perusahaan.

2. Data sekunder pada penelitian ini adalah berupa data ikhtisar kebijakan akuntansi perusahaan yang berhubungan dengan aset tetap dan catatan aset tetap.

\section{Teknik Pengumpulan Data}

Teknik pengumpulan data dalam penelitian ini yaitu sebagai berikut.

1. Penelitian Lapangan (Field Research)

2. Riset Kepustakaan (Library Research)

3. Media Elektronik

4. Wawancara (Interview)

\subsection{Metode Analisis}

Dalam menganalisa data yang terkumpul penulis menggunakan metode deskriptif dalam memahami data. Penulis mengidentifikasi data mengenai aset tetap PT. AKAM. Selanjutnya peneliti menganalisis lebih lanjut dengan cara membandingkan penyajian dan pengungkapan aset tetap pada PT. AKAM, apakah sudah sesuai dengan Standar Akuntansi Keuangan. Kemudian hasilnya diidentifikasi masing-masing dalam dua tahun laporan keuangan PT. AKAM tahun 2015 dan 2016 beserta catatannya. Setelah itu dirumuskan apakah penyajian dan pengungkapan terhadap masing-masing aset tetap tersebut telah memadai atau belum. Kemudian diambil keputusan dari hasil perbandingan tersebut .

\section{HASIL PENELITIAN DAN PEMBAHASAN \\ 4.1. Hasil Penelitian}

\section{Kebijakan Akuntansi Perusahaan}

Berkut ini merupakan aset tetap yang dimiliki PT. AKAM :

1. Tanah

2. Bangunan

3. Mesin dan Peralatan

4. Kendaraan

5. Inventaris Kantor

Kebijakan akuntansi atas aset tetap yaitu aset tetap diakui sebesar harga perolehan setelah dikurangi dengan akumulasi penyusutan. Semua aset tetap, kecuali hak atas tanah, disusutkan dengan menggunakan metode garis lurus (straight line method).

Beban pemeliharaan dan perbaikan diakui sebagai beban pada saat terjadinya. Pengeluaran yang memperpanjang masa manfaat aset atau yang memberikan manfaat ekonomis berupa peningkatan kapasitas atau mutu produksi, dikapitalisasi dan disusutkan sesuai dengan tarif penyusutan yang sesuai.

\section{Penyajian Aset tetap dalam Laporan Keuangan}

Dalam laporan keuangan PT. AKAM menyajikan sehubungan dengan aset tetap perusahaan pada laporan keuangan yakni di neraca, laporan laba rugi dan laporan arus kas. 
Laporan neraca PT. AKAM, terlihat aset tetap dilaporkan di posisi aset tidak lancar yang berada di bawah posisi aset lancar yang dinyatakan pada harga perolehan dikurangi akumulasi penyusutan. Berikut tabel penyajian aset tetap di neraca tahun 2015 dan tahun 2016.

Tabel 4.2 Penyajian Aset Tetap pada Neraca PT. AKAM tahun 2015 dan 2016

\begin{tabular}{|c|c|c|}
\hline Keterangan & $\begin{array}{c}\mathbf{2 0 1 5} \\
\text { (Rp) }\end{array}$ & $\begin{array}{c}\mathbf{2 0 1 6} \\
\text { (Rp) }\end{array}$ \\
\hline $\begin{array}{c}\text { Aset Tetap (harga perolehan-akumulasi } \\
\text { penyusutan) }\end{array}$ & 19.939 .420 .361 & 24.537 .331 .414 \\
\hline
\end{tabular}

Sumber: PT. AKAM (2018)

PT. AKAM menyajikan beban pemeliharaan dan perbaikan aset tetap pada catatan atas laporan keuangan perusahaan dan digolongkan ke dalam akun beban usaha pada laporan laba rugi. Pada tahun 2015 dan 2016 hanya disajikan beban pemeliharaan untuk kendaraan dan alat berat. PT. AKAM menjelaskan pada saat wawancara bahwa pada dua tahun tersebut tidak terjadi transaksi untuk perbaikan alat, karena perusahaan hanya melakukan perawatan atau pemeliharaan untuk aset tetap berupa kendaraan dan alat berat. Berikut tabel penyajian beban pemeliharaan dan perbaikan peralatan pada catatan atas laporan keuangan tahun 2015 dan 2016.

Tabel 4.3 Penyajian Beban Pemeliharaan dan Perbaikan Kendaraan dan Alat Berat pada Catatan atas Laporan Keuangan PT. AKAM tahun 2015 dan 2016

\begin{tabular}{|l|c|c|}
\hline \multicolumn{1}{|c|}{ Keterangan } & $\begin{array}{c}\mathbf{2 0 1 5} \\
(\mathbf{R p})\end{array}$ & $\begin{array}{c}\mathbf{2 0 1 6} \\
(\mathbf{R p})\end{array}$ \\
\hline $\begin{array}{l}\text { Beban pemeliharaan kendaraan dan alat } \\
\text { berat }\end{array}$ & 186.040 .500 & 25.908 .000 \\
\hline
\end{tabular}

Sumber: PT. AKAM (2018).

Beban penyusutan setiap jenis aset tetap seperti bangunan, kendaraan, peralatan, dan inventaris kantor di PT. AKAM disajikan pada daftar lampiran aset tetap perusahaan dan digolongkan ke dalam beban penyusutan pada catatan atas laporan keuangan. Beban penyusutan aset tetap perusahaan disajikan ke dalam laporan laba rugi pada akun beban usaha. Berikut tabel penyajian beban penyusutan PT. AKAM tahun 2015 dan 2016.

Tabel 4.4 Penyajian Beban Penyusutan pada Daftar Aset Tetap PT. AKAM tahun 2015 dan 2016

\begin{tabular}{|l|l|l|}
\hline \multicolumn{1}{|c|}{ Keterangan } & \multicolumn{1}{|c|}{$\begin{array}{c}\text { 2015 } \\
\text { (Rp) }\end{array}$} & \multicolumn{1}{c|}{$\begin{array}{c}\text { 2016 } \\
\text { (Rp) }\end{array}$} \\
\hline Beban Penyusutan Bangunan & 182.721 .107 & 171.973 .190 \\
\hline Beban Penyusutan Mesin dan Peralatan & 4.718 .319 .090 & 4.238 .061 .025 \\
\hline Beban Penyusutan Kendaraan & 2.225 .931 .269 & 2.296 .732 .270 \\
\hline Beban Penyusutan Inventaris Kantor & 92.510 .083 & 79.600 .050 \\
\hline
\end{tabular}

Sumber: PT. AKAM (2018)

PT. AKAM telah melakukan perhitungan penyusutan yang benar dengan menggunakan metode garis lurus (straight line method). Terjadi perbedaan total beban penyusutan pada tahun 2015 dan 2016. Pada aset tetap berupa bangunan, mesin dan peralatan dan inventaris kantor terjadi penurunan beban penyusutan dikarenakan beberapa asetnya telah habis manfaat ekonomisnya, sedangkan pada aset tetap berupa kendaraan terjadi peningkatan beban penyusutan dikarenakan terjadi penambahan aset berupa kendaraan bermotor. 
Pada tahun 2015 dan 2016, perusahaan menyajikan aset tetap pada aktivitas investasi yang dikarenakan perusahaan membayarkan sejumlah kas untuk memperoleh aset tetap. Berikut ini merupakan penyajian aktivitas untuk investasi aset tetap pada laporan arus kas.

Tabel 4.6

Penyajian Aktivitas Investasi Aset Tetap pada Laporan Arus Kas PT. AKAM tahun 2015 dan 2016

$\begin{array}{lll}\text { Keterangan } & 2015 & 2016 \\ (\text { Rp) } & (\mathbf{R p})\end{array}$

Arus Kas dari Aktivitas Investasi :

(Kenaikan) Penurunan Aset Tetap

$(2.794 .101 .980)$

$(11.384 .277 .588)$

Sumber: PT. AKAM, 2018

\section{Pengungkapan Aset Tetap}

Berdasarkan hasil penelitian, PT. AKAM mengungkapkan catatan aset tetap berupa lampiran daftar aset tetap dengan penyusutan. Daftar lampiran aset tetap dan penyusutan PT. AKAM tahun 2015 dan tahun 2016 berisi akun-akun aset tetap dengan mengklasifikasikan jenis-jenis aset tetap masing-masing berdasarkan harga perolehan dan tahun perolehan serta umur manfaatnya. Perusahaan juga mengungkapkan penambahan dan pengurangan aset tetap, penyusutan setiap jenis aset tetap yang dilampirkan dalam daftar aset tetap.

Laporan keuangan PT. AKAM mengungkapkan untuk setiap kelompok aset tetap adalah sebagai berikut.

1. Dalam pengukuran aset tetap perusahaan, PT. AKAM mengukur aset tetap sebesar model biaya perolehan.

2. Berdasarkan hasil penelitian, perusahaan mengungkapkan metode penyusutan pada catatan kebijakan akuntansi aset tetap perusahaan.

3. Metode penyusutan yang digunakan perusahaan pada tahun 2015 dan tahun 2016 yaitu metode garis lurus.

4. PT. AKAM mengungkapkan umur manfaat pada catatan kebijakan akuntansi perusahaan. Tetapi dalam lampiran aset tetap dan penyusutan, perusahaan tidak mengungkapkan mengenai umur manfaat dari setiap aset tetap karena menurut perusahaan itu sudah termuat dalam kebijakan akuntansi perusahaan maka perusahaan tidak mengungkapkan dalam lampiran aset tetap.

5. Perusahaan mengungkapkan jumlah tercatat bruto atau harga perolehan yang dikurangi akumulasi penyusutan pada catatan atas laporan keuangan perusahaan.

6. PT. AKAM mengklasifikasikan penggolongan jenis aset tetap perusahaan berdasarkan masing-masing golongan aset tetap.

7. PT. AKAM dalam catatan kebijakan akuntansi aset tetap mengungkapkan bahwa aset tetap yang sudah tidak digunakan lagi atau yang akan dijual, nilai tercatat dan akumulasi penyusutannya dikeluarkan dari laporan keuangan. Keuntungan dan kerugian yang dihasilkan dari penjualan aset tetap tersebut diakui dalam laporan laba rugi pada saat terjadinya. Tetapi PT. AKAM tidak mengungkapkan hal yang demikian, karena berdasarkan wawancara perusahaan belum melakukan pelepasan aset tetap.

\subsection{Pembahasan}

\section{Penyajian Aset Tetap Berdasarkan PSAK 16}

PT. AKAM telah menyajikan aset tetap sebesar nilai buku yaitu, harga perolehan dikurangi akumulasi penyusutan aset tetap yang sesuai dengan catatan laporan keuangan. Perusahaan juga telah menyajikan beban pemeliharaan dan perbaikan serta beban penyusutan 
pada laporan laba rugi sesuai dengan catatan laporan keuangan. Namun, pada tahun 2015 dan 2016 tidak disajikan keuntungan atau kerugian dari pelepasan aset tetap dikarenakan perusahaan tidak melakukan pelepasan aset tetap pada tahun tersebut.

Setiap jenis aset tetap seperti tanah, bangunan, inventaris kantor dan lain sebagainya telah dinyatakan dalam catatan atas laporan keuangan PT. AKAM. Sehingga pada neraca PT. AKAM tidak lagi disajikan secara terperinci seperti pada catatan atas laporan keuangan, melainkan hanya menyajikan total dari harga perolehan aset tetap dan akumulasi penyusutannya. Pada laporan arus kas PT. AKAM pada tahun 2015 dan 2016 disajikan pada aktivitas investasi yang dikarenakan perusahaan membayarkan sejumlah kas untuk memperoleh aset tetap. Berdasarkan pernyataan di atas PT. AKAM telah menyajikan aset tetap sesuai dengan PSAK No. 16.

\section{Pengungkapan Aset Tetap Berdasarkan PSAK 16}

PT. AKAM mengungkapkan aset tetap pada catatan aset tetap berupa lampiran daftar aset tetap dan penyusutan. Pada lampiran daftar aset tetap PT. AKAM tahun 2015 dan 2016 berisi akun-akun aset tetap dengan mengklasifikasikan jenis-jenis aset tetap berdasarkan harga perolehan, tanggal perolehan dan juga penambahan dan pengurangan aset tetap serta penyusutannya.

Dalam pengukuran aset tetap, PT. AKAM mengukur aset tetap sebesar dengan model biaya perolehan. Pengungkapan aset tetap diharuskan untuk mengungkapkan dasar penilaian yang digunakan untuk menentukan jumlah tercatat bruto. Jika lebih dari satu dasar digunakan jumlah tercatat bruto untuk dasar setiap kategori harus diungkapkan.

PT. AKAM juga mengungkapkan metode penyusutan yang digunakan pada kebijakan akuntansi aset tetap perusahaan. Metode penyusutan yang digunakan PT. AKAM yaitu metode garis lurus (straight line method).

Dari beberapa pernyataan di atas, dapat diketahui pengungkapan aset tetap diketahui masih ada hal-hal yang belum diungkapkan oleh perusahaan dikarenakan perusahaan tidak melakukan aktivitas sesuai akun tersebut seperti, perolehan melalui kombinasi bisnis, peningkatan atau penurunan akibat dari revaluasi sesuai dengan paragraf 31, 39 dan 40 serta dari rugi penurunan nilai yang diakui atau dibalik dalam penghasilan komprehensif lain sesuai dengan PSAK 48 (Penurunan Nilai Aset), pembalikan rugi penurunan nilai dalam laba rugi, selisih kurs neto, jumlah komitmen kontraktual untuk memperoleh aset tetap dan jumlah kompensasi dari pihak ketiga untuk aset tetap yang mengalami penurunan nilai, hilang atau dihentikan.

\section{KESIMPULAN DAN SARAN}

\subsection{Kesimpulan}

Berdasarkan hasil dan pengumpulan dan analisis data yang telah dilaksanakan, maka dapat ditarik kesimpulan sebagai berikut.

1. PT. AKAM dalam hal ini melaksanakan kegiatan akuntansinya berpedoman pada Kebijakan Akuntansi PT. AKAM yang pada prinsipnya sudah mendekati Standar Akuntansi Keuangan.

2. Penyajian aset tetap pada laporan keuangan perusahaan telah memadai karena telah sesuai dengan PSAK No.16.

3. Pengungkapan aset tetap masih belum menyajikan pengungkapan aset tetap dikarenakan perusahaan tidak melakukan aktivitas sesuai akun tersebut seperti, perolehan melalui kombinasi bisnis, peningkatan atau penurunan akibat dari revaluasi sesuai dengan paragraf 31,39 dan 40 serta dari rugi penurunan nilai yang diakui atau dibalik dalam penghasilan komprehensif lain sesuai dengan PSAK 48 (Penurunan Nilai Aset), pembalikan rugi penurunan nilai dalam laba rugi, selisih kurs neto, jumlah komitmen kontraktual untuk memperoleh aset tetap dan jumlah kompensasi 
dari pihak ketiga untuk aset tetap yang mengalami penurunan nilai,hilang atau dihentikan.

\subsection{Saran}

Metode dan kebijakan yang sudah sesuai dengan PSAK No. 16 tetap dipertahankan agar laporan keuangan perusahaan yang disajikan bisa tetap akurat dan bisa memiliki kesamaan/keseragaman secara umum dengan perusahaan lainnya yang sudah menerapkan kebijakan akuntansi yang sesuai dalam laporan keuangannya.

\section{DAFTAR PUSTAKA}

Ernawati. 2014. Analisis Penerapan Standart Akuntansi Keuangan (PSAK No. 16) Atas Aset Tetap Pada PT. Pelayaran Liba Marindo Tanjung Pinang. Universitas Maritim Raja Ali Tanjung Pinang.

Hery. 2014. Akuntansi Aset, Liabilitas, dan Ekuitas. Penerbit PT Gramedia Widiasarana Indonesia. Jakarta.

Ikatan Akuntan Indonesia (IAI). 2016a. Penyajian Laporan Keuangan. Pernyataan Standar Akuntansi Keuangan No.1. (Revisi 2015). DSAK-IAI. Jakarta. 2016b. Aset Tetap. Pernyataan Standar Akuntansi Keuangan No.16. (Revisi 2015). DSAK-IAI. Jakarta.

Kartikahadi, Hans., Sinaga, Uli Rosita., Syamsul, Merliyana., Siregar, Sylvia Veronica., Wahyuni, Ersa Tri. 2015. Akuntansi Keuangan Berdasarkan SAK Berbasis IFRS. Edisi Kedua. Buku 1. Penerbit Ikatan Akuntan Indonesia. Jakarta.

Kasmir 2016. Analisis Laporan Keuangan. Raja Grafindo Persada. Jakarta.

Lubis, Rahmat Hidayat. 2017. Pengantar Akuntansi Jasa. Penerbit Gava Media. Yogyakarta.

Martani. Dwi., Sylvia Veronica Siregar., Ratna Wardhani., Aria Farahmita., Edward Tanujaya. 2016. Akuntansi Keuangan Menengah Berbasis PSAK (PSAK Konvergensi IFRS). Edisi 2 Buku 1. Penerbit Salemba Empat. Jakarta Selatan.

Mustamin, Fitrah. 2013. Analisis Pengakuan, Pengukuran dan Pelaporan Aktiva Tetap Berdasarkan PSAK No. 16. Universitas Sam Ratulangi Manado. Jurnal EMBA ISSN 2303-1174. Vol. 1.

Pontoh, E. L., Morasa, J., dan Budiarso N. S.. 2016. Evaluasi Penerapan Perlakuan Akuntansi Terhadap Aktiva Tetap Berdasarkan PSAK No.16 Tahun 2011 pada PT. Nichindo Manado Suisan. Universitas Sam Ratulangi Manado. Jurnal Emba ISSN 2303-1174. Vol.4.

Pradana, Yoga \& Tuban Drijah Herawati. 2015. Penerapan PSAK No.16 tentang Aset Tetap pada PT. Perkebunan Nusantara XI (Persero) PG Seodhono Ngawi. Jurnal Ilmiah Mahasiswa FEB Universitas Brawijaya Malang. Volume 3 No.1.

Suwardjono. 2014. Teori Akuntansi Perekayasaan Pelaporan Keuangan. Edisi Ketiga. Cetakan Kedelapan. BPFE. Yogyakarta.

Wild, John J., Ken W Shaw dan Barbara Chiappetta. 2014. Financial Accounting Information For Decisions is A Asian Adaption Of Fundamental Accounting $20^{\text {th }}$ Edition. Mc Gra Hill Aducation (Asia). Singapore. 